\title{
HUBUNGAN SPRITUALIS DENGAN STRES PADA LANJUT USIA DI DESA GASARIBU WILAYAH KERJA PUSKESMAS LAGUBOTI KABUPATEN TOBA SAMOSIR
}

\author{
Tumpal Manurung, Minar Lenny Situmorang, Indah Sinurat \\ Program Studi D3 Keperawatan, STIKes Arjuna \\ E-mail : manroetumpal@gmail.com
}

\begin{abstract}
Advanced age is someone who has reached the age of 60 years and over. In the elderly found various physical and psychological changes that cause stress. But with spirituality as adaptation and coping, the elderly will be able to cope with the stress they experience. This study aims to identify the relationship between spirituality and stress in the elderly by using correlative design. The sample in this study were 50 elderly people in the village of Gasaribu Laguboti Toba Samosir. Determination of the number of samples based on power analysis tables and taken using simple random sampling technique. Data collection was conducted on April 4 to May 4, 2018 using a questionnaire containing questions and statements about demographic, spirituality and stress data in the elderly. From the research, it was found that $88 \%$ of the elderly were at a high level of spirituality and $12 \%$ at moderate levels of spirituality. Meanwhile $76 \%$ of the elderly were in the category of mild stress and $24 \%$ in the moderate stress category. Spirituality is negatively related to a weak relationship with stress in the elderly $(r=-0.182)$ with an unacceptable significance value (p>0.05) so it can be concluded that the research hypothesis is unacceptable, meaning there is no relationship between spirituality and stress in further age in the village of Gasaribu Laguboti Toba Samosir. This caused by various factors including socio-economic factors, culture, gender, education, social environment, crisis and transition aspects, elderly personal characteristics, one's adaptation involving multiple dimensions, livelihood and shelter assistance and the opportunity to develop potential self. Information provided can help improve nursing services for the elderly, especially psychologically.
\end{abstract}

Keywords: Spirituality, Stress, Elderly

\begin{abstract}
Abstrak
Usia lanjut adalah seseorang yang telah mencapai usia 60 tahun ke atas. Pada lansia ditemukan berbagai perubahan fisik dan psikologis yang dapat menyebabkan stres. Tetapi dengan adaptasi dan koping spiritualitas, para lansia akan mampu mengatasi tekanan yang mereka alami. Penelitian ini bertujuan untuk mengidentifikasi hubungan antara spiritualitas dan stres pada lansia dengan menggunakan desain korelatif. Sampel dalam penelitian ini adalah 50 orang lanjut usia di desa Gasaribu Laguboti Toba Samosir. Penentuan jumlah sampel berdasarkan tabel analisis daya dan diambil menggunakan teknik simple random sampling. Pengumpulan data dilakukan pada 4 April hingga 4 Mei 2018 menggunakan kuesioner yang berisi pernyataan tentang data demografi, kerohanian, dan stres pada lansia. Dari penelitian, ditemukan bahwa 88\% lansia memiliki tingkat kerohanian yang tinggi dan $12 \%$ dengan tingkat kerohanian yang sedang. Sementara itu $76 \%$ lansia berada dalam kategori stres ringan dan $24 \%$ dalam kategori stres sedang. Spiritualitas berhubungan negatif dengan hubungan yang lemah dengan stres pada lansia $(r=-0,182)$ dengan nilai signifikansi yang tidak dapat diterima $(p>0,05)$ sehingga dapat disimpulkan bahwa hipotesis penelitian tidak dapat diterima, artinya tidak ada hubungan antara spiritualitas dan stres pada usia lanjut di desa Gasaribu Laguboti Toba Samosir. Hal ini disebabkan oleh berbagai faktor termasuk faktor sosial-ekonomi, budaya, gender, pendidikan, lingkungan sosial, aspek krisis dan transisi, karakteristik pribadi lansia, adaptasi seseorang yang melibatkan berbagai dimensi, bantuan mata pencaharian dan tempat tinggal dan kesempatan untuk mengembangkan potensi diri. Informasi
\end{abstract}


yang diberikan dapat membantu meningkatkan layanan keperawatan untuk lansia, terutama secara psikologis.

Kata Kunci: Spiritualitas, Stres, Lansia

\section{PENDAHULUAN}

Laju perkembangan kesehatan di Indonesia salah satunya dicerminkan dari peningkatan lanjut usia. Proporsi penduduk lanjut usia di atas 60 tahun juga semakin meningkat. Pada tahun 2016 mencapai 7,6\% atau sekitar 16 juta jiwa. Selanjutnya diperkirakan pada tahun 2005-2010 jumlah lanjut usia di atas 60 tahun meningkat sebanyak 8,5 \% dari seluruh penduduk Indonesia yaitu sekitar 19 juta jiwa. Hal inilah yang menempatkan Indonesia pada urutan keempat terbanyak di dunia setelah Cina, India dan Amerika (Depkes, 2014).

Peningkatan jumlah lanjut usia ini harus disertai dengan penyediaan sarana dan fasilitas kesehatan, sosial dan aspek lainnya yang memadai. Hal ini disebabkan perubahan-perubahan yang terjadi pada beberapa aspek (Ardila, S. 2013). Perubahanperubahan yang signifikan pada lanjut usia, antara lain: perubahan gaya hidup dan keuangan, merawat pasangan yang sakit, menghadapi kematian, kehilangan pasangan hidup dan orang-orang yang dicintai, ketidakmampuan fisik dan penyakit kronis, kesepian serta perubahan lainnya (Azizah, L. M, 2011). Keadaan ini juga dapat mengindikasikan suatu ketergantungan kepada orang lain (Ardila, S. 2013).

Lebih lanjut perubahan-perubahan ini menyebabkan kecenderungan timbulnya stres bagi lanjut usia baik jangka pendek maupun jangka panjang. Dalam keadaan stres seseorang dapat mengalami gangguan fisik dan mental. Khusus bagi lanjut usia, kemampuan untuk kembali normal setelah mengalami keadaan yang mengakibatkan stres sangat sulit karena menurunnya sistem yang merespon stres dalam otak. Selain itu pada sistem imunitas, stres akan menghadapkan lanjut usia pada resiko besar mendapatkan penyakit (Azizah, L. M, 2011). Dari berbagai kajian tentang spiritualitas dilaporkan adanya hubungan yang erat antara spiritualitas dengan penurunan stres pada lanjut usia. Diyakini bahwa melalui dimensi spiritual yang menyangkut kepercayaan terhadap Tuhan sebagai penguasa tertinggi, perasaan yang menyatu dengan alam dan dunia sebagai satu-kesatuan yang utuh, dan pengertian yang positif tentang makna dan tujuan hidup berperan ketika lanjut usia mengalami stres. Melalui spiritualitas yang tinggi pula seseorang akan berusaha memelihara hubungan personal dan menganggap penting setiap peristiwa dalam kehidupannya (Potter \& Perry, 2009).

Ardila, S. (2013), mengungkapkan bahwa lanjut usia yang sering mengikuti kegiatan ibadah dan berpartisipasi di dalamnya menunjukkan peningkatan status kesehatan, menurunkan insiden penyakit kronis dan peningkatan koping yang efektif terhadap stres. Ismail, A. \& Santoso, H. (2009). menyatakan bahwa spiritualitas dapat membantu wanita-wanita lanjut usia untuk hidup di masyarakat. Dimana doa sebagai unsur spiritualitas digunakan dalam mengatasi stres, penderitaan dan sebagai sarana untuk memperoleh kedamaian.

Pada umumnya para lanjut usia akan mulai memikirkan masalah kematian dan makna hidupnya. Oleh karena itu mereka akan mengembangkan spiritualitas untuk memahami pengertian hidup dan mati Ardila, S. (2013), menemukan bahwa perilaku koping yang dilakukan oleh lanjut usia berhubungan dengan spiritualitas seseorang.

Berdasarkan pendapat terdahulu mengemukakan bahwa karakteristik populasi dapat mempengaruhi stres dan spiritualitas seseorang.

\section{Spiritualitas}

\section{Pengertian Spiritualitas}

Spiritualitas adalah kepercayaan atau suatu hubungan dengan kekuatan yang lebih tinggi, pencipta dan sumber segala kekuatan. Sementara itu E. Hight. (2011) menguraikan spiritualitas sebagai suatu yang multidimensi, yaitu dimensi eksisitensial dan dimensi 
agama. Dimensi eksistensial berfokus pada tujuan dan arti kehidupan, sedangkan dimensi agama lebih berfokus pada hubungan seseorang dengan Tuhan Yang Maha Penguasa. Azizah, L. M (2011), juga menyimpulkan bahwa terdapat hubungan yang terus-menerus antara dua dimensi tersebut.

Lain halnya dengan Azizah, L. M (2011), menguraikan bahwa spiritualitas sebagai konsep dua dimensi yaitu dimensi vertikal yang merupakan hubungan dengan Tuhan atau Yang Maha Tinggi yang menuntun kehidupan seseorang, sedangkan dimensi horizontal adalah hubungan seseorang dengan diri-sendiri, dengan orang lain dan dengan lingkungan. Kebutuhan spiritual juga merupakan kebutuhan untuk mempertahankan atau mengembalikan keyakinan dan memenuhi kewajiban agama, serta kebutuhan untuk mendapatkan maaf atau pengampunan, mencintai, menjalin hubungan penuh rasa percaya dengan Tuhan (Azizah, L. M, 2011).

\section{Karakteristik Spiritualitas}

Beberapa karakteristik yang meliputi hubungan spiritualitas antara lain adalah hubungan dengan diri-sendiri, hubungan dengan alam, hubungan dengan orang lain, dan hubungan dengan Tuhan (Azizah, L. M, 2011).

2.1 Hubungan dengan Diri-sendiri

Hubungan ini merupakan kekuatan dari dalam diri seseorang yang meliputi pengetahuan diri yaitu siapa dirinya, apa yang dapat dilakukannya dan juga sikap yang menyangkut kepercayaan pada diri-sendiri, kepercayaan pada masa depan, ketenangan pikiran, serta keselarasan dengan diri-sendiri. Kekuatan yang timbul dari diri seseorang membantunya menyadari makna dan tujuan hidupnya, di antaranya: memandang pengalaman hidupnya sebagai pengalaman yang positif, kepuasan hidup, optimis terhadap masa depan, dan tujuan hidup yang semakin jelas (E.Hight., 2011).

\subsection{Hubungan dengan Orang Lain}

Hubungan ini terbagi atas harmonis dan tidak harmonisnya hubungan dengan orang lain. Keadaan harmonis meliputi pembagian waktu, pengetahuan dan sumber secara timbal balik, mengasuh anak, mengasuh orang tua dan orang yang sakit, serta meyakini kehidupan dan kematian. Sedangkan kondisi yang tidak harmonis berkaitan dengan konflik dengan orang lain dan resolusi yang menimbulkan ketidakharmonisan dan friksi E.Hight. (2011).

Hubungan dengan orang lain ini lahir dari kebutuhan akan keadilan dan kebaikan, menghargai kelemahan dan kepekaan orang lain, rasa takut akan kesepian, keinginan dihargai dan diperhatikan, dan lain sebagainya. Dengan demikian apabila seseorang mengalami kekurangan ataupun mengalami stres maka orang lain dapat memberi bantuan psikologis dan sosial (Kaplan \& Sadock. 2010).

\subsection{Hubungan dengan Alam}

Harmoni merupakan keadaan yang menggambarkan hubungan seseorang dengan alam yang meliputi pengetahuan tentang tanaman, pohon, margasatwa, iklim dan berkomunikasi dengan alam serta melindungi alam tersebut (Nasir, A dan Abdul, M. 2011). Terjalinnya hubungan baik antara manusia dengan alam akan menghindarkan perusakan alam.

2.4 Hubungan dengan Tuhan

Hubungan ini meliputi agamais maupun tidak agamais. Keadaan ini menyangkut sembahyang dan berdoa, keikutsertaan dalam kegiatan ibadah, perlengkapan keagamaan, serta bersatu dengan alam (E.Hight., 2011).

Dari penjelasan di atas, secara ringkas dapat dinyatakan bahwa seseorang terpenuhi kebutuhan spiritualitasnya apabila mampu merumuskan arti personal yang positif tentang tujuan keberadaannya di dunia, mengembangkan arti penderitaan serta meyakini hikmah dari suatu kejadian atau penderitaan, menjalin hubungan yang positif dan dinamis, membina integritas personal dan merasa diri berharga. Selain itu pemenuhan kebutuhan spiritualitas tersebut tercapai bila seseorang mampu merasakan kehidupan yang terarah terlihat melalui 
harapan dan mengembangkan hubungan antar manusia yang positif (Hamid, A. Y. 2010).

\section{Faktor-Faktor yang mempengaruhi Spiritualitas}

Ada beberapa faktor penting yang mempengaruhi spiritualitas seseorang yaitu pertimbangan tahap perkembangan, keluarga, latar belakang etnik dan budaya, pengalaman hidup sebelumnya, krisis, serta pengalaman hidup sebelumnya (Gusvita, E, 2015)

\subsection{Tahap Perkembangan}

Berdasarkan hasil penelitian terhadap anak-anak dengan empat agama yang berbeda ditemukan bahwa mereka mempunyai persepsi tentang Tuhan dan bentuk sembahyang yang berbeda menurut usia, seks, agama, dan kepribadian anak. Tema utama yang diuraikan oleh semua anak tentang Tuhan mencakup gambaran tentang Tuhan yang bekerja melalui kedekatan dengan manusia dan saling keterikatan dengan kehidupan. Persepsi anak lainnya adalah mempercayai bahwa Tuhan terlibat dalam perubahan dan pertumbuhan diri serta tranformasi yang membuat dunia tetap segar, penuh kehidupan dan berarti. Selain itu anak juga meyakini Tuhan mempunyai kekuatan dan takut mengahadapi kekuasaan Tuhan. Namun ada juga yang mempersepsikannya sebagai gambaran cahaya atau sinar (Hamid, A. Y. 2010).

\subsection{Keluarga}

Peran orangtua sangat menentukan dalam perkembangan spiritualitas anak. Dalam hal ini yang penting bukan apa yang diajarkan oleh orangtua kepada anaknya tentang Tuhan, tetapi apa yang anak pelajari tentang Tuhan, kehidupan dan diri-sendiri dari perilaku orangtua mereka. Oleh karena keluarga merupakan lingkungan terdekat dan pengalaman pertama anak dalam mempersepsikan kehidupan di dunia, maka pandangan anak pada umumnya diwarnai oleh pengalaman mereka dalam berhubungan dengan orangtua dan saudaranya (Nasir, A dan Abdul, M. 2011).

\subsection{Latar Belakang Etnik dan Budaya}

Sikap, keyakinan dan nilai dipengaruhi oleh latar belakang etnik dan sosial budaya. Pada umumnya seseorang akan mengikuti tradisi agama dan spiritual keluarga. Anak belajar pentingnya menjalankan kegiatan agama, termasuki nilai moral dari hubungan keluarga dan peran serta dalam berbagai bentuk kegiatan keagamaan (Gusvita, E, 2015).

3.4 Pengalaman Hidup Sebelumnya

Pengalaman hidup baik yang positif maupun negatif dapat mempengaruhi spiritualitas seseorang dan sebaliknya juga dipengaruhi oleh bagaimana seseorang mengartikan secara spiritual pengalaman tersebut (E.Hight., 2011). Peristiwa dalam kehidupan sering dianggap sebagai suatu cobaan yang diberikan Tuhan kepada manusia untuk menguji imannya (Hamid, A. Y. 2010).

4. Spritualitas terhadap stres pada lanjut usia.

Keyakinan agama dan pengalaman spiritual merupakan bagian penting dalam memberikan warna bagi kehidupan lanjut usia. Transisi kehidupan seperti saat-saat terakhir dalam hidup dan kematian menantang seseorang untuk mendalami keyakinannya dan bertumbuh (Hamid, A. Y. 2010). Agama atau keyakinan spiritual dan pengalaman dapat menjadi instrumen dalam menolong lanjut usia dalam menghadapi takut (Arumsari, N, S. 2014) Dari uraian yang telah dikemukakan di atas menunjukkan adanya hubungan antara spiritualitas dan stres pada lanjut usia di beberapa negara di dunia. Namun tidak ada penelitian sebelumnya di Indonesia, khususnya di Sumatera Utara. Dengan demikian maka penelitian ini menjadi penting untuk mengidentifikasi hubungan antara spiritualitas dengan stres pada lanjut usia di Binjai.

\section{METODE}

Jenis penelitian ini adalah correlation study, dengan jumlah sampel sebanyak 50 orang dan menggunakan teknik random sampling. Pengambilan data 
dilakukan di Desa Gasaribu Wilayah kerja Puskesmas Laguboti Kabupaten Toba Samosir pada bulan November 2018. Pengumpulan dengan cara pembagian kuesioner. Kuesioner dibuat sendiri oleh peneliti yang telah diuji validitas dan reliabilitasnya (Sugiyono, 2017). Analisa data dilakukan dengan menggunakan uji korelasi Pearson pada tingkat kepercayaan $95 \%$. Hak-hak responden dilindungi dari berbagai aspek dalam penelitian ini.

HASIL

Karakteristik Responden

\begin{tabular}{|c|c|c|}
\hline \multirow[t]{2}{*}{ Usia } & Frekuensi & Persentase \\
\hline & (Orang) & $(\%)$ \\
\hline 60-70tahun & 22 & 44 \\
\hline 71-81tahun & 18 & 36 \\
\hline 82-92tahun & 17 & 14 \\
\hline $93-100$ & 3 & 6 \\
\hline Jumlah & 50 & 100 \\
\hline \multicolumn{3}{|l|}{ J. Kelamin } \\
\hline Pria & 23 & 46 \\
\hline Wanita & 27 & 54 \\
\hline Jumlah & 50 & 100 \\
\hline \multicolumn{3}{|l|}{ Pendidikan } \\
\hline $\mathrm{SD}$ & 29 & 58 \\
\hline SMP & 5 & 10 \\
\hline SMA & 2 & 4 \\
\hline Tidak & 14 & 28 \\
\hline sekolah & & \\
\hline Jumlah & 50 & 100 \\
\hline \multicolumn{3}{|l|}{ Suku } \\
\hline Batak & 50 & 100 \\
\hline Status & & \\
\hline Menikah & 30 & 60 \\
\hline Duda/janda & 20 & 40 \\
\hline Jumlah & 50 & 100 \\
\hline \multicolumn{3}{|l|}{$\begin{array}{l}\text { Kegiatan } \\
\text { spritual }\end{array}$} \\
\hline Kebaktian & 50 & 100 \\
\hline Jumlah & 50 & 100 \\
\hline
\end{tabular}

Hasil penelitian menunjukkan bahwa sebagian besar responden berada pada usia 60-70 tahun (44\%) dan sebagian kecil pada usia 93-100 tahun (6\%). Seluruh responden beragama Kristen (100\%). Mayoritas responden berjenis kelamin wanita (54\%), suku Batak (100\%), pendidikan terakhir SD $(58 \%)$ dan status responden menikah $(60 \%)$ dan seluruhnya mengikuti kebaktian (100\%).

\section{Spiritualitas}

Hasil penelitian menunjukkan dimana mayoritas lanjut usia $(88 \%)$ berada pada tingkat spiritualitas tinggi dan tingkat spiritualitas sedang sebanyak $12 \%$, serta tidak ada responden yang mengalami tingkat spiritualitas rendah.

\begin{tabular}{lcc}
\hline $\begin{array}{l}\text { Tingkat } \\
\text { Spritualitas }\end{array}$ & $\begin{array}{c}\text { Frekuensi } \\
\text { (orang) }\end{array}$ & $\begin{array}{c}\text { Persentase } \\
(\boldsymbol{\%})\end{array}$ \\
\hline Tinggi & 44 & 88 \\
\hline Sedang & 6 & 12 \\
\hline Rendah & - & - \\
\hline Jumlah & 50 & 100 \\
\hline
\end{tabular}

\section{Stres Pada Lanjut Usia}

Data hasil penelitian bahwa 38 responden (76\%) dapat dikategorikan pada derajat stres ringan dan 12 responden (24\%) pada kategori derajat stres sedang dan tidak ada responden pada kategori derajat stres berat.

\begin{tabular}{lcc}
\hline $\begin{array}{l}\text { Stres pada } \\
\text { lansia }\end{array}$ & $\begin{array}{c}\text { Frekuensi } \\
\text { (orang) }\end{array}$ & $\begin{array}{c}\text { Persentase } \\
(\boldsymbol{\%})\end{array}$ \\
\hline Berat & - & - \\
\hline Sedang & 12 & 24 \\
\hline Ringan & 38 & 76 \\
\hline Jumlah & 50 & 100 \\
\hline
\end{tabular}

\section{Hubungan Spiritualitas Dengan Stres Pada Lanjut Usia}

Hasil penelitian didapatkan nlai koefisien korelasi Pearson Product Moment atau $\mathrm{r}$ sebesar -0,182. Berdasarkan tabel kriteria penafsiran korelasi menurut Burns \& Groove (2001) bahwa kedua variabel tersebut memiliki hubungan negatif dengan interpretasi lemah ( $\mathrm{r}$ pada $-0,1$ sampai $-0,3$ ). Kemudian pada hubungan antara kedua variabel tersebut dapat dikatakan tidak signifikan, dimana $\mathrm{p}>0,05$. 
PEMBAHASAN

\section{Spiritualitas Pada Lanjut Usia Di Desa Gasaribu Kecamatan Laguboti}

Dari hasil distribusi frekuensi dan persentase berdasarkan spiritualitas responden di Desa Gasaribu Kecamatan Laguboti Kabupaten Toba Samosir, didapatkan bahwa $88 \%$ responden pada tingkat spiritulitas tinggi dan $12 \%$ responden pada tingkat spiritualitas sedang dalam kehidupannya saat ini. Hasil penelitian ini sesuai dengan yang dinyatakan oleh (Azizah, L. M, 2011) dimana perkembangan spiritualitas membantu lanjut usia menghadapi penyesuaian-penyesuaian pada masa tua dan (Arumsari, N, S. 2014) melalui beberapa studi menyatakan religi berperan penting dalam mengatasi stres dengan sumber koping yang biasa dilakukan yaitu berdoa dan berserah diri pada Tuhan. Khususnya menurut agama mayoritas responden yang diteliti bahwa rajin beribadah dan melakukan shalat fardhu serta melakukan istikharah membantu seseorang terhindar dari stres (Azizah, L. M, 2011). Spiritualitas yang sehat memberi kedamaian dan penerimaan diri dan didasarkan pada hubungan yang berkelanjutan dengan Sang Pencipta. Penyakit dan perasaan kehilangan dapat menantang spiritualitas seseorang dalam proses perkembangan mental (Nasir, A dan Abdul, M. 2011).

Hasil kajian yang dilakukan pada anggota American Association of Retired Person menemukan spiritualitas menjadi suatu perwujudan dukungan sosial yang penting dalam meningkatkan kesehatan lanjut usia (E.Hight., 2011). Di samping itu, Stanley and Patricia, (2006). juga menyatakan ilmu pengetahuan menangani masalah-masalah penuaan lebih lambat dibanding tradisi-tradisi spiritual yang telah mengenali masa tua sebagai tahap yang harus dihadapi dengan cara yang spesifik.

\section{Stres pada lanjut usia di Desa Gasaribu Kecamatan Laguboti Kabupaten Toba Samosir}

Dari hasil distribusi frekuensi dan persentase stres pada lanjut usia di Desa
Gasaribu Kecamatan Laguboti Kabupaten Toba Samosir menunjukkan bahwa 76\% responden termasuk pada kategori derajat stres ringan, $24 \%$ pada kategori derajat stres sedang dan tidak ada responden pada kategori derajat stres yang tinggi. Hasil penelitian ini sesuai dengan pendapat (Dewi, S.R, 2014). yang mempelajari hubungan antara stres dan masa penuaan yang sangat kompleks. Lanjut usia umumnya lebih rawan terhadap stresor fisik yang muncul di samping stresor psikologis dan psikososial yang juga turut menimbulkan stres. Demikian juga hasil penelitian yang menunjukkan perbandingan kategori derajat stres yang ringan daripada kategori derajat sedang sesuai dengan hasil studi yang menyatakan bahwa kebanyakan lanjut usia lebih mampu memanajemen stres yang mereka alami karena selama menjalani masa dewasa, seseorang belajar untuk memanajemen berbagai stres yang dialaminya (E.Hight., 2011)

Lebih lanjut, berdasarkan data dari penelitian yang dilakukan terhadap lanjut usia di Desa Gasaribu Kecamatan Laguboti Kabupaten Toba Samosir stresor yang muncul pada responden adalah keadaan fisik yang semakin menurun (42\%) dan beban akibat kesehatannya yang menurun (24\%), dimana keluhan yang timbul berasal dari penyakit yang kini mereka derita. Penurunan kesehatan yang dipicu oleh penurunan kemampuan sel di dalam tubuh serta kemampuan fisiologis dalam penyesuaian terhadap lingkungan (Sunaryo, 2009).

Ditambahkan juga oleh Hamid, A. Y. (2010), yang memandang perubahanperubahan menyangkut kehidupan sosial ekonomi dan keluarga berperan pada kesehatan fisik dan mental lanjut usia. Namun pada responden di Desa Gasaribu Kecamatan Laguboti Kabupaten Toba Samosir perubahan-perubahan tersebut tidak terlalu banyak mempengaruhi stres yang timbul. Hal ini disebabkan responden yang telah mampu menyesuaikan dirinya dengan lingkungan yang ditinggalinya. Hidup berpisah dari keluarga tidak terlalu membebani kehidupannya karena interaksi 
sosial di antara komunitas lanjut usia yang telah terjalin dimana mereka dapat berbagi satu dengan yang lain tidak membuat mereka terisolasi dari kehidupan sosial.

\section{Hubungan Spiritualitas Dengan Stres Pada Lanjut Usia.}

Hasil analisa statistik dalam penelitian ini adalah bahwa spiritualitas yang terbagi atas kategori tinggi, sedang dan rendah berhubungan secara negatif dengan hubungan yang lemah dengan stres pada lanjut usia $(\mathrm{r}=-0.182)$. Hasil analisa hubungan kedua variabel tersebut tidak memiliki nilai signifikansi yang dapat diterima, dimana $p>0.05$ sehingga dapat disimpulkan bahwa hipotesa penelitian ditolak, artinya bahwa pernyataan hipotesa adanya hubungan antara spiritualitas dengan stres pada lanjut usia tidak dapat diterima.

Dari hasil distribusi frekuensi dan persentase berdasarkan spiritualitas diperoleh data bahwa $88 \%$ lanjut usia memiliki spiritualitas yang tinggi. Beberapa penelitian melaporkan peningkatan religiusitas berlangsung seiring dengan pertambahan usia (E.Hight., 2011) dan juga berbagai kajian yang memaparkan bahwa individu yang sejahtera memiliki nilai spiritual yang tinggi. Akan tetapi dua faktor yang berkaitan sekalipun belum tentu mengindikasikan penyebab satu dengan yang lain (Townsend, M.C. 2009).

Sebagaimana yang dinyatakan E.Hight., (2011), bahwa spiritualitas juga menjadi sumber dukungan untuk banyak orang termasuk lanjut usia ketika menghadapi stres dan dari hasil beberapa studi menunjukkan bahwa spiritualitas sangat penting dalam usaha mengatasi stres, seharusnya dapat ditemukan hubungan yang signifikan antara spiritualitas dengan stres pada lanjut usia di Desa Gasaribu Kecamatan Laguboti Kabupaten Toba Samosir. Namun kemungkinan spiritualitas ternyata lebih relevan bagi seseorang yang menderita suatu penyakit. Sesuai Hawari, D., (2011), mengatakan tentang spiritualitas sebagai koping terhadap penyakit kronik dimana hasil penelitian ini membuktikan bahwa spiritualitas berperan dalam koping adaptif dan menjadikan penderita penyakit kronik tersebut lebih kuat.

Adanya hubungan yang lemah namun tidak signifikan antara spiritualitas dengan stres pada lanjut usia kemungkinan oleh adanya berbagai faktor yang mempengaruhi. Hubungan spiritualitas dengan stres pada lanjut usia sebenarnya dipengaruhi oleh faktor-faktor lain seperti sosial ekonomi, budaya, pendidikan, jenis kelamin, lingkungan sosial, aspek krisis dan transisi serta karakteristik personal lanjut usia tersebut. Keseluruhan hal ini berperan dalam menghadapi transisi maupun perubahan yang merupakan stresor bagi lanjut usia (Dewi, S.R, 2014). Pada hasil penelitian didapati faktor yang cenderung mempengaruhi tidak adanya hubungan spiritualitas dengan stres adalah karakteristik personal responden yaitu pendidikan yang rendah (58\%).

Ismail, A. \& Santoso, H. (2009). dalam bukunya menuliskan bahwa spiritualitas bukan faktor utama dalam mengatasi stres pada lanjut usia. Sama halnya dengan yang diungkapkan (Dewi, S.R, 2014). bahwa kemampuan adaptasi seseorang terhadap stres melibatkan totalitas seseorang yang juga menyangkut dimensi fisik, perkembangan, emosional dan sosial sebagai satu-kesatuan. Dukungan sosial sebagai bagian dari dimensi sosial merupakan hal yang penting sebagai proteksi terhadap stresor yang berat maupun sedang dalam situasi sulit sekalipun (Hamid, A. Y. 2010). Sementara itu dari hasil penelitian diperoleh dimensi fisik merupakan bagian yang menonjol daripada dimensi lainnya yang terlihat dari kecemasan responden akan keadaan fisik yang semakin menurun (42\%) dan beban akibat kesehatannya yang menurun $(24 \%)$

Berdasarkan analisa faktor-fakor tersebut dapat diasumsikan bahwa stres yang dialami pada lanjut usia dipengaruhi oleh berbagai faktor dan adaptasinya melibatkan beberapa dimensi dalam kehidupan yang berhubungan dengan stres. Meskipun spiritualitas pada lanjut usia bukanlah hal utama yang berhubungan dengan stres, 
penting juga menjadikan spiritualitas bagian dari koping lanjut usia dalam menjalani masa tuanya.

\section{KESIMPULAN}

Pada distribusi frekuensi

karakteristik responden sebagian besar adalah lanjut usia dengan usia terbanyak 60-70 tahun (44\%), jenis kelamin wanita (54\%), agama Kristemn (100\%), suku Batak (100\%), pendidikan terakhir SD (58\%), status menikah (60\%), dan mengikuti kegiatan pengajian $(100 \%)$. Sebagian besar responden memiliki tingkat spiritualitas tinggi (88\%) dan yang lainnya memiliki tingkat spiritualitas sedang (12\%). Mayoritas responden $(76 \%)$ dikategorikan pada derajat stres ringan dan $24 \%$ pada stres sedang.

Spiritualitas berhubungan secara negatif dengan hubungan yang lemah terhadap stres pada lanjut usia $(r=-0.182)$ dengan nilai signifikansi yang tidak dapat diterima $p=0.207(p>0.05)$, sehingga dapat disimpulkan bahwa hipotesa penelitian tidak dapat diterima, artinya tidak ada hubungan spiritualitas dengan stres pada lanjut usia di Desa Gasaribu Kecamatan Laguboti Kabupaten Toba Samosir

Adanya hubungan yang lemah dengan nilai signifikansi yang tidak dapat diterima antara kedua variabel tersebut, kemungkinan disebabkan oleh berbagai faktor di antaranya faktor sosial ekonomi, budaya, jenis kelamin, pendidikan, lingkungan sosial, aspek krisis dan transisi serta karakteristik personal lanjut usia. Selain itu, adaptasi seseorang yang melibatkan beberapa dimensi dan bantuan penghidupan, tempat tinggal serta adanya kesempatan untuk mengembangkan potensi diri dalam melakukan berbagai kegiatan turut mempengaruhi stres

\section{SARAN}

1. Bagi praktek keperawatan

Dalam praktek keperawatan gerontik maupun komunitas perlu mempertimbangkan penyuluhan yang mengarah pada kebutuhan-kebutuhan lanjut usia yang aktual menyangkut perubahan-perubahan yang dialaminya maupun masalah yang yang sedang dihadapi khususnya di posyanduposyandu lansia yang diakan oleh Puskesmas. Perlunya konseling di samping perawatan medis yakni spiritualitas sangat diperlukan sebagai dukungan perawat untuk meningkatkan kesehatan mental dan fisik serta memenuhi kebutuhan akan informasi bagi lanjut usia.

2. Bagi pendidikan keperawatan

Perawatan pada lanjut usia melibatkan berbagai dimensi dalam menjalani masa tuanya sehingga mahasiswa keperawatan perlu memperhatikan kebutuhan akan dukungan psikologis yang dapat membantu lanjut usia menghadapi perubahan-perubahan yang terjadi pada dirinya. Dengan demikian mahasiswa keperawatan akan mampu memberikan layanan kesehatan bagi lanjut usia sesuai dengan kebutuhannya.

3. Bagi penelitian selanjutnya.

Spiritualitas merupakan bagian dari adaptasi stres yang dapat digunakan sebagai dukungan sosial maupun emosional. Perbedaan antara hasil penelitian dengan tinjauan pustaka yang didapatkan dapat dijadikan sebagai data masukan bagi penelitian selanjutnya tentang spiritualitas dengan stres pada lanjut usia. Penelitian lanjutan juga perlu dilakukan dengan instrumen yang lebih valid dan jumlah sampel yang lebih representatif agar dapat menggambarkan keadaan yang sebenarnya tentang hubungan spiritualitas dengan stres pada lanjut usia.

\section{Daftar Pustaka}

Ardila, S. (2013). Integritas Ego pada Lanjut Usia Wanita di Panti Wreda Hanna Yogyakarta. Jurnal Keperawatan. Universitas Sanata Dharma Yogyakarta. 3 (1): 14-24.

Arumsari, N, S. (2014). Pengaruh Reminiscence Therapy Terhadap Tingkat Stres pada Lansia di PTSW Unit Budi Luhur, Kasongan, Bantul, 
Yogyakarta. Tesis. Program Studi Ilmu Keperawatan Fakultas Kedokteran dan Ilmu Kesehatan Universitas Muhamadiyah Yogyakarta

Azizah, L. M. (2011). Keperawatan Jiwa (Aplikasi Praktik Klinik). Graha Ilmu. Yogyakarta.

Dewi, S.R. (2014). Buku ajar keperawatan gerontik. Yogyakarta: Deepublish.

E.Hight. (2011). Spirituality and Medical Pratice: Using the HOPE Questions as a Pratical Tool for Spiritual Assessment. American Family Physician. 63 (81-88)

Gusvita, E. (2015). Hubungan Antara Tingkat Spiritualitas dengan Kesiapan Lanjut Usia dalam Menghadapi Kematian di Desa Pucangan Kecamatan Kartasura. Skripsi. Fakultas Ilmu Kesehatan Universitas Muhammadiyah Surakarta

Hamid, A. Y. (2010). Buku Pedoman Askep Jiwa-1 Keperawatan Jiwa Teori Dan Tindakan Keperawatan. Departemen Kesehatan Republik Indonesia. Jakarta. .

Hawari, D., (2011). Depresi dalam Manajemen Stress, Kecemasan, Depresi. Jakarta: FKUI

Ismail, A. \& Santoso, H. (2009). Memahami krisis lanjut usia. Jakarta: Gunung mulia.

Kaplan, H.I., Sadock, B.J. (2010). Retardasi Mental dalam Sinopsis Psikiatri. Tangerang : Binarupa Aksara

Nasir, A dan Abdul, M. (2011). Dasar-Dasar Keperawatan Jiwa. Salemba Medika. Jakarta.

Potter, A. \& Perry, A.G. (2009). Fundamental Keperawatan, Edisi 7. Cetakan 1. Salemba Medika. Jakarta.

Sugiyono. (2017). Metode Penelitian Kuantitatif, Kualitatif, dan R\&D. Bandung: Alfabeta, CV.

Sunaryo. (2009). Konsep Dasar Keperawatan Jiwa. EGC. Jakarta.

Townsend, M.C. (2009). Psychiatric Mental Health Nursing: Concepts of Care in
Evidence Based Pratice. 6th edition. FA Davis Company. Philladelphia. 